\title{
Antibacterial Activity of Ocimum gratissimum L. Essential Oil
}

\author{
Celso Vataru Nakamura, Tania Ueda-Nakamura, Erika Bando, \\ Abrahão Fernandes Negrão Melo, Díogenes Aparício Garcia Cortez*, \\ Benedito Prado Dias Filho/ ${ }^{+}$
}

\author{
Departamento de Análises Clínicas * Departamento de Farmácia e Farmacologia, Universidade Estadual de \\ Maringá, Av. Colombo 5790, 87100-330 Maringá, PR, Brasil
}

The essential oil (EO) of Ocimum gratissimum inhibited Staphylococcus aureus at a concentration of $0.75 \mu \mathrm{g} / \mathrm{ml}$. The minimal inhibitory concentrations (MICs) for Shigella flexineri, Salmonella enteritidis, Escherichia coli, Klebsiella sp., and Proteus mirabilis were at concentrations ranging from 3 to 12 $\mu \mathrm{g} / \mathrm{ml}$. The endpoint was not reached for Pseudomonas aeruginosa $(\geq 24 \mathrm{mg} / \mathrm{ml})$. The MICs of the reference drugs used in this study were similar to those presented in other reports. The minimum bactericidal concentration of EO was within a twofold dilution of the MIC for this organism. The compound that showed antibacterial activity in the EO of $\mathrm{O}$. gratissimum was identified as eugenol and structural findings were further supported by gas chromatography/mass spectra retention time data. The structure was supported by spectroscopic methods.

Key words: Ocimum gratissimum - essential oil - eugenol - antimicrobial activity

Ocimum gratissimum L. (Labiatae) is widely distributed in tropical and warm temperature regions. The plant is commonly used in folk medicine to treat different diseases, e.g. upper respiratory tract infections, diarrhea, headache, ophthalmic, skin diseases, pneumonia, and also as a treatment for cough, fever, and conjunctivitis (Corrêa 1932, Onajobi 1986).

Previous studies showed that the essential oils (EO) of four Ocimum species grown in Rwanda, i.e. O. canum, O. gratissimum, $O$. trichodon and O. urticifolium, display antimicrobial activity (Janssen et al. 1989). It has been reported that the volatile oil of this plant contains mostly phenols, particularly thymol (Olivier 1960, Sainsbury \& Sofowora 1971) and that these are probably responsible for its reported antimicrobial action.

The present work reports on the antibacterial activity of both EO and purified active compound using bioautography plates, diffusion techniques on solid media and macrobroth dilution methods in broth media.

\footnotetext{
This work was supported by grants from CNPq (no. 530079/93-3).

${ }^{+}$Corresponding author. Fax: +55-44-261.4490. E-mail: bene@dac.uem.br

Received 26 January 1999

Accepted 22 March 1999
}

\section{MATERIALS AND METHODS}

General - ${ }^{1} \mathrm{H}$ - and ${ }^{13} \mathrm{C}$-nuclear magnetic resonance at 200 and $50 \mathrm{MHz}$ respectively, tetramethylsilane as standard, in a Bruker ARX. GC/MS: capillary gas chromatography was performed a Hewlett-Packard 5890 gas chromatography equipped with a Hewlett-Packard 5780 mass spectrometer. Used one capillary column (cc) HP-1 with $25 \mathrm{~m} \times 0.20 \mathrm{~mm}$, temperature programmed: $150-280^{\circ} \mathrm{C}$ at $6^{\circ} \mathrm{C} / \mathrm{min}$. Mass spectra were compared with that from authentic samples and with spectra from the literature.

Plant material - O. gratissimum was collected in March 1996 in Maringá, Paraná, Brazil. A voucher no. Sp.P1.1197,175 is deposited at the Herbarium of the Instituto Agronômico de Campinas, SP, Brazil.

Steam distillation - Fresh leaves of $O$. gratissimum were cut into pieces and subjected to steam distillation. The distillate was then extracted with petroleum ether. The resulting extract was dried on anhydrous sodium sulfate. Petroleum ether was removed carefully and the EO was obtained.

Microbial cultures growth conditions - Test microorganisms included the following Gram-positive bacteria: Staphylococcus aureus (ATCC 25923), and for Gram-negative: Escherichia coli (ATCC 25922), Pseudomonas aeruginosa, Proteus mirabilis, Klebsiella sp., Salmonella enteritidis, and Shigella flexineri. Cultures of these bacteria were grown in Mueller-Hinton broth (Difco) at $37^{\circ} \mathrm{C}$ and maintained on slopes of nutrient agar (Difco) at 
$4^{\circ} \mathrm{C}$. All microorganisms were derived from the stock culture of the Department of Clinical Analyses of the Universidade Estadual de Maringá.

Antimicrobial activity assay - EO of $O$. gratissimum was tested for antimicrobial activity using the diffusion technique on solid media. Sterile, $8 \mathrm{~mm}$ diameter stainless steel cylinders were placed on plates of Mueller-Hinton agar (Difco), which had been surface spread with $0.1 \mathrm{ml}$ of logarithmic phase bacteria at a density adjusted to a $0.5 \mathrm{McF}$ arland turbidity standard $\left(10^{8}\right.$ colonyforming units $[\mathrm{CFU}] / \mathrm{ml}$.). To each of duplicated cylinders, $100 \mu \mathrm{l}$ of filter sterilized test EO (diluted with Tween 80 at $2 \%$ ) at working concentrations of $25-50 \mu \mathrm{g}$ were added. The plates were then incubated for $24 \mathrm{hr}$ at $37^{\circ} \mathrm{C}$. The results were recorded by measuring the zones of growth inhibition surrounding the cylinders. Control cylinders contained $100 \mu \mathrm{l}$ of dimethyl sulfoxide (DMSO). In addition, gentamycin (Frumtost), ampicillin (Bayer), streptomycin (Climax) were used as controls in the assay.

Minimal inhibitory concentration (MIC) - The EO was tested for antibacterial activity using the macrobroth dilution method in broth media Mueller-Hinton (Difco). In these experiments, 0.4 $\mathrm{ml}$ of a suspension containing $1 \times 10^{6} \mathrm{CFU} / \mathrm{ml}$ was added to $3.6 \mathrm{ml}$ of susceptibility test broth containing serial twofold dilutions of the EO in glass test tubes $(13$ by $100 \mathrm{~mm})$ fitted with loose plastic nonscrew caps. All tubes were incubated in air at $37^{\circ} \mathrm{C}$ for $24 \mathrm{hr}$ before being read. The MIC was considered the lowest concentration of the sample that prevented visible growth. Minimum bactericidal concentrations (MBCs) were determined by subculturing, $10 \mu \mathrm{l}$ from each negative tube and from the positive growth control. MBCs were defined as the lowest concentration yielding negative subcultures or only one colony. All samples were examined in duplicate in three separate experiments.

Isolation and identification of major constituent - The EO (450 mg) was subjected to column chromatography on silica gel with a gradient of Hexane-Acetyl Acetate (98:2, 95:5, 90:10, 80:20, and 50:50) to $100 \%$ Acetyl Acetate and 20 fractions (F1-F20) were collected. The thin-layer chromatography (TLC) analysis of these fractions yielded four fractions F6, F15, F17, and F19.

Thereafter, the fractions F15 and F17 were rechromatographed on silica gel with HexaneAcetyl Acetate (95:5) to give one active compound $(315 \mathrm{mg})$. The purified active compound was identified using spectral data.

Thin layer chromatography - The EO and fractions (F6, F15, F17, and F19) obtained as described above were analyzed by TLC on silica gel G plates
$(20 \times 10 \mathrm{~cm})$ using the solvent system HexaneAcetyl Acetate (95:5). TLC plates were run in duplicate and one set was used as the reference chromatogram. Spots and bands were visualized by UV irradiation (254 and 366nm) and by spraying with Vanillin/Sulfuric acid reagent (Stahl 1969). The other set was used for bioautography.

Bioautography - Chromatogram developed as described above was placed in sterile glass square with cover and an inoculum of $S$. aureus containing $10^{6} \mathrm{CFU} / \mathrm{ml}$ in molten Mueller Hinton agar was distributed over the plates. After solidification of the medium, the TLC plate was incubated overnight at $37^{\circ} \mathrm{C}$. Inhibition zones indicated the presence of active compounds.

\section{RESULTS AND DISCUSSION}

Fresh leaves of $O$. gratissimum yielded $0.21 \%$ of EO. The analysis of the EO by CG/MS revealed a major component $(67 \%)$ with a retention time of $14.22 \mathrm{~min}$

Table I reports the inhibition zones of OE determined for six strains of Gram-positive or Gramnegative bacteria using the diffusion technique on solid media. Proteus, Klebsiella, Escherichia, Salmonella, Staphylococcus and Shigella showed inhibition zones ranging from 13 to $25 \mathrm{~mm}$. $P$. aeruginosa was considered resistant since no inhibition zone was observed.

\section{TABLE I}

Antimicrobial activity of essential oil as determined by diffusion technique on solid media (stainless steel cylinders)

\begin{tabular}{lrcc}
\hline & \multicolumn{3}{c}{ Concentrations } \\
& $(\mathrm{mg} / 100 \mathrm{ml}$ dimethyl sulfoxide $)$ \\
\cline { 2 - 4 } & 24 & 48 & Control \\
\cline { 2 - 4 } Microorganism & \multicolumn{3}{c}{$\begin{array}{c}\text { Inhibition } \\
\text { zone (mm) }\end{array}$} \\
\hline Proteus mirabilis & 13 & 19 & 0 \\
Klebsiella sp. & 16 & 18 & 0 \\
Escherichia coli & 16 & 17 & 0 \\
Salmonella enteritidis & 16 & 17 & 0 \\
Staphylococcus aureus & 17 & 21 & 0 \\
Shigella flexineri & 25 & 29 & 0 \\
Pseudomonas aeruginosa & 0 & 0 & 0 \\
\hline
\end{tabular}

MICs for all bacterial test are reported in Table II. The EO inhibited $S$. aureus at a concentration of $0.75 \mu \mathrm{g} / \mathrm{ml}$. In contrast to the relatively low MIC of EO for Gram-positive bacteria, Gram-negative bacteria belonging to the genera Shigella, Salmonella, Escherichia, Klebsiella, and Proteus were inhibited by EO with MICs ranging from 3 to 12 $\mu \mathrm{g} / \mathrm{ml}$. Pseudomonas was not inhibited by EO at 
concentrations as high as $24 \mu \mathrm{g} / \mathrm{ml}$. The MICs of the reference drugs used in this study were similar to those presented in other reports (data not shown). The minimum concentration of antimicrobial necessary to kill an organism, MBC, should be equal to or greater than the MIC for that microbe. In this study six bacterial strains presented MBCs which were within one twofold dilution of the MIC obtained for these organisms.

\section{TABLE II}

Minimal inhibitory concentration (MIC) and minimum bactericida concentration (MBC) of essential oil from Ocimum gratissimum $\mathrm{L}$.

\begin{tabular}{lcc}
\hline Microorganism & $\begin{array}{c}\text { MIC } \\
(\mu \mathrm{g} / \mathrm{ml})\end{array}$ & $\begin{array}{c}\text { MBC } \\
(\mu \mathrm{g} / \mathrm{ml})\end{array}$ \\
\hline Staphylococcus aureus & 0.75 & 1.5 \\
Shigella flexineri & 3 & 6 \\
Salmonella enteritidis & 3 & 6 \\
Escherichia coli & 6 & 12 \\
Klebsiella sp. & 6 & 12 \\
Proteus mirabilis & 12 & 24 \\
Pseudomonas aeruginosa & $\geq 24$ & $\mathrm{NT}$
\end{tabular}

NT: not tested.

The activity of EO from $O$. gratissimum against S. aureus was higher than that of the other bacteria tested. EO was also active against members of the family Enterobacteriaceae. The MICs for Shigella, Salmonella, Escherichia, Klebsiella, and Proteus ranged from 3 to $12 \mu \mathrm{g} / \mathrm{ml}$.

The EO was subjected to successive cc on silica gel and the resulting fractions were analyzed by TLC on silica gel. Chromatograms were run in duplicate and one set was used as the reference chromatogram (Fig.1A). The other set was assayed for bioautography and showed inhibition zone against $S$. aureus indicating the presence of active compounds (Fig.1B). The compound that showed antibacterial activity, was identified as eugenol (Moffat et al. 1986) by ${ }^{1} \mathrm{H}$ and ${ }^{13} \mathrm{C}$ NMR, supported by GC/MS, by retention time, and by comparison with an authentic sample.

Jedlickova et al. (1992) studied the antibacterial properties of Vietnamese cajeput oil and ocimum oil in combination with antibacterial agents. According to these authors, the plant products were found to be effective medicines for local application in modern medicine practice. They also suggested on the basis of in vitro tests the synergistic action of these two kinds of medicines.

Recently, Lima et al. (1993) tested in vitro antifungal activity of 13 EO obtained from plants against dermatophytes. Of the tested oils, $O$. gratissimum was found to be the most active, inhibiting $80 \%$ of the dermatophyte strains tested and

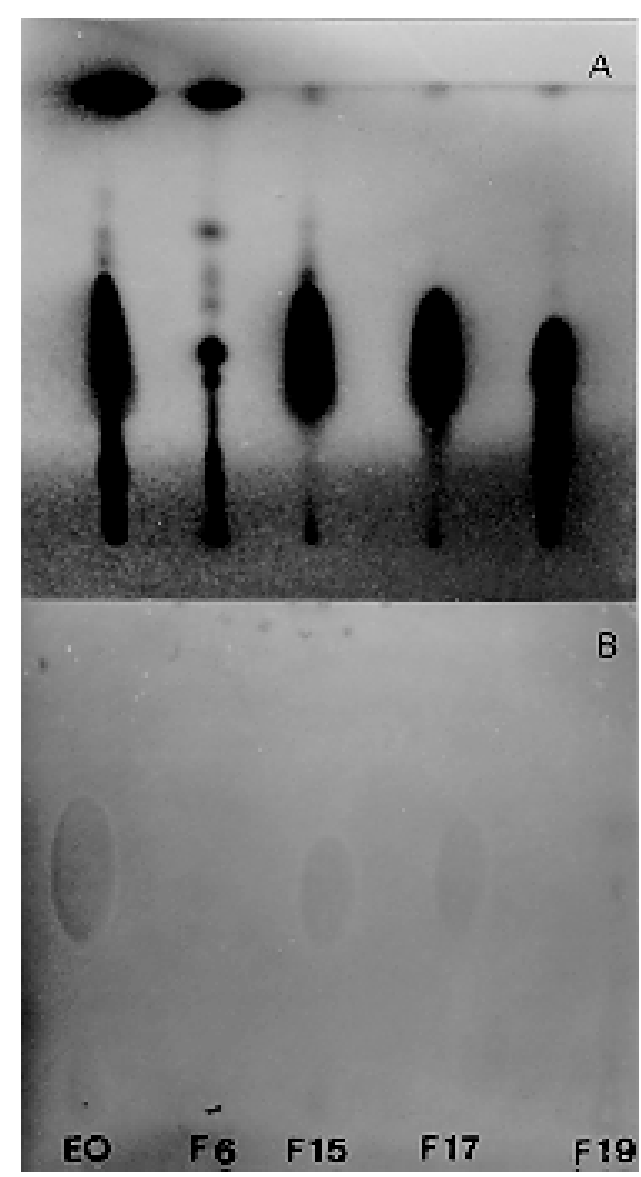

Thin-layer chromatography plates were run in duplicate and one set was visualized by Vanillin/Sulfuric acid spray reagent (A). The other set was used for bioautography with Staphylococcus aureus (B) as described in Materials and Methods. EO: essential oil; F6, F15, F17, and F19 fractions.

producing zones greater than $10 \mathrm{~mm}$ in diameter. More recently, Nwosu and Okafor (1995) reported the antifungal activities of extracts of ten medicinal plants collected from southeastern Nigeria against seven pathogenic fungi. According to these authors, $O$. gratissimum inhibited the growth of Trichophyton rubrum and T. mentagrophytes. They also suggested the possible use of certain plant extracts in the treatment of subcutaneous phycomycosis in humans and animals. Other reports have shown smooth muscle contracting lipidsoluble principles (Onajobi 1986) and antimutagenic activity (Obaseiki-Ebor et al. 1993) in organic solvent extracts of leaves of $O$. gratissimum.

Ilori et al. (1996) have reported the antidiarrhoeal activities of leaf extracts of $O$. gratissimum investigated by disc diffusion and tube dilution methods. These authors have shown that the ex- 
tracts were active against Aeromonas sobria, E. coli, P. shigelloides, S. typhi and S. dysenteriae. They have also shown that the MIC for those organisms ranged from 8 to $50 \mathrm{mg} / \mathrm{ml}$, while the MBC were from 8 to $62 \mathrm{mg} / \mathrm{ml}$. The present study shows that gram-negative bacteria belonging to the genera Proteus, Klebsiella, Salmonella, Escherichia, and Shigella were inhibited by EO with MICs ranging from 3 to $12 \mu \mathrm{g} / \mathrm{ml}$. Other reports have shown MIC results similar to or higher than ours (Ramonoelina et al. 1987, Janssen et al. 1989). These differences may be explained by susceptibility testing conditions, physicochemical characteristics of the oil, and even strain-to-strain differences. In vivo data may be helpful in determining the potential usefulness of the essential oil from O. gratissimum

\section{ACKNOWLEDGMENTS}

To Marinete Martinez for help in the experiments.

\section{REFERENCES}

Corrêa MP 1932. Dicionário das Plantas Úteis do Brasil, IBDF, Ministério da Agricultura, Rio de Janeiro, 63 pp.

Ilory M, Sheteolu AO, Omonibgehin EA, Adeneye AA 1996. Antidiarrhoeal activities of Ocimum gratissimum (Lamiaceae). J Diarrhoeal Dis Res 14: 283-285.

Janssen AM, Scheffer JJ, Ntezurubanza L, Baerheim Svendsen A 1989. Antimicrobial acitivities of some Ocimum species grown in Rwanda. J Ethnopharmacol 26: 57-63.
Jedlickova Z, Motti O, Sery V 1992. Antibacterial properties of the Vietnamese cajeput oil and ocimum oil in combination with anticaterial agents. $J \mathrm{Hyg}$ Epidemiol Microbiol Immunol 36: 303-309.

Lima EO, Gompetz OF, Giesbrecht AM, Paulo MQ 1993. In vitro antifungal activity of essential oils obtained from officinal plants against dermatophytes. Mycoses 36: 333-336.

Moffat AC, Jackson JV, Moss MS, Widdop B 1986. Clarke's Isolation and Identification of Drugs, The Pharmaceutical Press, London, 609 pp.

Nwosu MO, Okafor JI 1995. Preliminary studies of the antifungal activities of some medical plants against Basidiobolus and some other pathogenic fungi. $M y$ coses 38: 191-195.

Obaseiki-Ebor EE, Odukoya K, Telikepally H, Mitscher LA, Shankel DM 1993. Antimutagenic activity of extracts of leaves of four common edible vegetable plants in Nigeria (West Africa). Mutat Res 302: 109117.

Oliver B 1960. Medicinal Plants in Nigeria, Nigerian College of Arts, Science and Technology, Nigeria, $42 \mathrm{pp}$.

Onajobi FD 1986. Smoth muscle contracting lipidicsoluble principles in chromatographic fractions of Ocimum gratissimum. J Ethnopharmacol 18: 3-11.

Ramanoelina AR, Terrom GP, Bianchini JP, Coulanges P 1987. Antibacterial action of essential oils extratted from Madagascar plants. Arch Inst Pasteur Madagascar 53: 217-226.

Sainsbury M, Sofowora EA 1971. Essential oil from the leaves and inflorescence of Ocimum gratissimum. Phytochemistry 10: 3309-3310.

Stahl E 1969. Thin-layer Chromatography, SpringerVerlag, New York, 904 pp. 